alone cannot account for the discrepancies noted by Taitz and Byers (1972) it is probable that in addition the instructions are not followed carefully.

We have begun to investigate the scoop weights obtained by mothers and the preliminary results of this study confirm that scoops are often overfilled. Since the instructions for filling scoops differ widely from brand to brand it is obviously important that all personnel concerned with infant feeding should be thoroughly conversant with the instructions for each brand of milk. However, the variations that we have found when following the instructions carefully raise the question of whether the scoop is a satisfactory measure at all. The danger of hyperosmolar feeding could be reduced by greater dilution of full cream milks with water, and allowing the baby a slightly larger volume of feed.

\section{Conclusions}

The addition of mineral substances in the manufacture of milks used for infant feeding probably alters the mineral composition slightly, but the addition of whey neutralized with sodium bicarbonate as used in the manufacture of Trufood Formula 4 results in an unusually high concentration of sodium. As the addition of even small amounts of substances may have an important bearing on an infant's nutrition and metabolism, we think that the chemical formulae and amounts of all substances added in the processing of such milks should be made readily available by the manufacturers. Furthermore, we suggest that as well as the content of protein the amounts of sodium, potassium, calcium, and phosphorus present in the powders or liquids should be written on the packet and expressed in both $\mathrm{mg} / 100 \mathrm{~g}$ and $\mathrm{mEq} / \mathrm{kg}$. When a scoop is provided the weight of powder contained in a scoop should also be displayed on the container in both grammes and ounces. Milk powders that reconstitute to a composition close to that of cows' milk present an osmotic load to the kidneys that may endanger water balance in some circumstances. Since this risk is greatly increased by the tendency to overfill scoops and to make feeds too concentrated, a specific inquiry on these points should be made when dealing with any case of dehydration or hypernatraemia. This risk could be reduced by recommending a greater dilution with water, by offering water as a drink during hot weather, and by making feeds up half strength during minor illness when there is anorexia.

We gratefully acknowledge the help of Mr. J. Mitchell, of the department of chemical pathology, Hospital for Sick Children, London, who performed the nitrogen analyses.

\section{References}

Colle, E., Ayoub, E., and Raile, R. (1958). Pediatrics, 22, 5.

Edelman, C. M., junr., and Barnet, H. L. (1960). Fournal of Pediatrics, 56, 154

Finberg, L., and Harrison, H. E. (1955). Pediatrics, 16, 1

Fomon, S. J., and May, C. D. (1958). Pediatrics, 22, 101.

Gomorri, G. (1942). Fournal of Laboratory and Clinical Medicine, 27, 955. Hasnain, N., and Abraham, J. M. (1968). British Medical fournal, 1, 55.

Heeley, A. M., and Talbot, N. B. (1955). American fournal of Diseases of Children, 90,251 .

Hey, E. N., and Katz, G. (1969). Fournal of Physiology, 200, 605.

Kon, S. K., and Cowie, A. T. (1961). Milk: The Mammary Gland and its Secretion, vol 2. New York, Academic Press

Kon, S. K., and Mawson, E. M. (1950). Medical Research Council. Special

Report Series, No. 269.
McCance, R. A., and Widdowson, E. M. (1969). Medical Research Council. Special Report Series, No. 297.

Macaulay, D., and Watson, M. (1967). Archives of Disease in Childhood, $42,485$.

Macy, I. G., Kelly, H. J., and Sloan, R. E. (1953). Publication 254, Washington D.C., National Academy of Sciençes National Research Council.

Poláčk, E., Vocel, J., Neugebauerová, L., Sebková, M., and Vétchetová, E. (1965). Archives of Diseases in Childhood, 40, 291.

Simpson, H., and O'Duffy, J. (1967). British Medical fournal, 3, 536.

Slater, J. E. (1961). British fournal of Nutrition, 15, 83.

Stern, G. M., Jones, R. B., and Fraser, A. C. L. (1972). Archives of Disease in Childhood, 47,468 .

Taitz, L. S. (1971). British Medical fournal, 1, 315.

Taitz, L. S., and Byers, H. O. (1972). Archives of Diseas? in Childhood, 47, 257.

Widdowson, E. M. and Dickerson, J. W. T. (1961). In Mineral Metabolism, vol. II, part A, ed. C. L. Comar and F. Bronner. New York, Academic Press.

Winberg, J. (1959). Acta Paediatrica Scandinavica, 48, 318.

Ziegler, E. E., and Fomon, S. J. (1971). Fournal of Pediatrics, 78, 561.

\title{
Inaccuracies in Measurement of Dried Milk Powders
}

\author{
P. W. WILKINSON， T. C. NOBLE， G. GRAY， O. SPENCE
}

British Medical fournal, 1973, 2, 15-17

\section{Summary}

Infant feeds made up from dried milk are known to be hazardous if the mixture is too concentrated. Tests with five commercial brands of dried milk showed that nurses, midwives, and mothers often made up feeds incorrectly; in most cases the amount of powder used was excessive.

Fewer mistakes would be made if scoops were standardized or, better, if the milk was made up in small, accurately weighed packets.

Newcastle General Hospital, Newcastle upon Tyne NE4 6BE P. W. WILKINSON, M.R.C.P., D.C.H., Registrar, Neonatal Unit T. C. NOBLE, F.R.C.P., D.C.H., Consultant Paediatrician G. GRAY, S.R.N., s.C.M., Departmental Sister, Special Care Baby Unit O. SPENCE, M.P.s., Deputy Chief Pharmacist

\section{Introduction}

Overfeeding of infants with cows' milk can be dangerous if it causes hypernatraemia and undesirable if it results in obesity.

Hyperosmolar dehydration (Finberg and Harrison, 1955; Colle et al., 1958; Ziegler and Fomon, 1971; Taitz and Byers, 1972), and obesity due to overfeeding in infancy (Eid, 1970; Taitz, 1972; Shukla et al., 1972) have been the subjects of many papers over the last two decades. Taitz and Byers (1972) described cases of hyperelectrolytaemia due to gross mistakes in the reconstitution of both dried powdered milk and evaporated liquid milk preparations, and Hytten and MacQueen (1954) drew attention to widespread inaccuracies in the making of feeds by mothers of different competence. Hytten and MacQueen's comprehensive study showed the wide variations in the content of calories, protein, fat, and carbohydrate which were found when reconstituted feeds were analysed in the laboratory.

Cows' milk contains more than three times as much sodium as human milk, and since the infant kidney cannot always excrete a solute load above $700 \mathrm{mOsm} / 1$. (Winberg, 1959; Poláček et al., 1965 ) then any reduction of fluid intake, increase in concentra- 
tion of feeds, or increase in extrarenal fluid loss may result in a rise in the levels of sodium and nitrogenous substances in the extracellular fluid (Ziegler and Fomon, 1971). These last authors emphasize that half-cream milk preparations provide a slightly greater solute load than do full cream milks. It is possible that milk formulae reconstituted in concentrations greater than the manufacturers' recommendations might tip the balance towards a state of hypernatraemia in borderline cases of dehydration.

It is reasonable to suppose that the consistent ingestion of over-strong feeds may be a factor in the production of infantile obesity, and this is acknowledged by Eid (1970) and Illingworth (1972).

While some of the examples quoted may have been due to maternal carelessness we feel that the instructions for reconstitution of dried milk given by some manufacturers are insufficiently precise, and the shape of some dried milk scoops is such that consistently accurate measurement is difficult, even when the user is intelligent and experienced. A preliminary experiment suggested that there might be as much as $100 \%$ difference in the weights of milk powder measured out by different people using the same scoop, so we decided to study the frequency and magnitude of such errors on a wider scale.

\section{Method}

Five commercial brands of dried powdered milk in common use were tested with the scoops provided. Three of these brands were measured out by different groups of volunteers, including mothers in postnatal wards, midwives, and nurses working in a special care baby unit. Less extensive trials were carried out with the other two preparations, which were each tested by only five people. The subjects taking part in the experiments were different for each milk powder tested, but the circumstances of the trials were kept constant. Those testing the powders were required to measure out four scoopfuls of the preparation into paper bags and the contents of the bags were weighed in the hospital pharmacy. The powders were presented to the subjects in the manufacturers' containers, all of which had instructions printed on the outside, and knives for levelling off the scoops were provided if they were asked for.

\section{Results}

In every case the scoop was dipped into the milk powder (although in one brand the directions indicated that the powder should be poured into the scoop with a spoon), and in those cases where no knife was used for levelling the powder to the top of the scoop the powder was flattened and possibly compressed by drawing the scoop out of the packet with the open face pressed against the inside of the pack.

The results of using three of the powders are shown in tables I, II, and III and of using the other two powders with a smaller number of subjects in table IV.

TABLE I-Weights of Four Scoopfuls of Milk Powder A Measured by Different Groups of Subjects Using Appropriate Scoop. Manufacturer's Intended Weight of Four Scoopfuls is $12.8 \mathrm{~g}^{*}$ Roller-dried preparation.

\begin{tabular}{|c|c|c|c|c|c|c|}
\hline \multirow{2}{*}{\multicolumn{5}{|c|}{ Groups of Subjects }} & \multicolumn{2}{|c|}{ Weight of Powder (g) } \\
\hline & & & & & Range & Mean \\
\hline 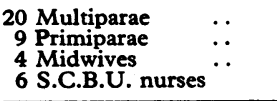 & $\begin{array}{l}\cdots \\
\because \\
\cdots\end{array}$ & $\begin{array}{l}\ldots \\
\because \\
\cdots\end{array}$ & $\begin{array}{l}\ldots \\
\cdots \\
\cdots\end{array}$ & $\begin{array}{l}\because \\
\because \\
\because\end{array}$ & $\begin{array}{l}13 \cdot 4-23 \cdot 6 \\
12 \cdot 3-22 \cdot 7 \\
13 \cdot 3-19 \cdot 3 \\
14 \cdot 9-19 \cdot 6\end{array}$ & $\begin{array}{l}17 \cdot 5 \\
16 \cdot 6 \\
16 \cdot 3 \\
17 \cdot 1\end{array}$ \\
\hline Knife used for levellingt & . & .. & .. & .. & $12 \cdot 3-17 \cdot 7$ & $14 \cdot 6$ \\
\hline
\end{tabular}

*Manufacturer's instructions: "Fill the measure with food using a spoon, then strike off level for correct quantity. (A slightly heaped teaspoonful of food equals one

†Only 11 of these 39 subjects used a knife.
Preparations A, B, and C were roller-dried, preparations $\mathrm{X}$ and $\mathrm{Y}$ were spray-dried. Spray-dried preparations are denser than roller-dried powders. That part of the instruction on the packet or tin relating to the filling of the scoop is quoted in each case.

TABLE II-Weights of Four Scoopfuls of Milk Powder B Using Appropriate Scoop. Intended Weight of Milk Powder in This Preparation is $14.0 \mathrm{~g}^{*}$ Roller-dried Preparation.

\begin{tabular}{|c|c|c|c|c|c|c|}
\hline \multirow{2}{*}{\multicolumn{5}{|c|}{ Groups of Subjects }} & \multicolumn{2}{|c|}{ Weight of Powder (g) } \\
\hline & & & & & Range & Mean \\
\hline $\begin{array}{ll}20 & \text { Multiparae } \\
10 & \text { Primiparae } \\
5 & \text { Midwives }\end{array}$ & $\begin{array}{l}\ldots \\
\cdots \\
\cdots\end{array}$ & $\begin{array}{l}\ldots \\
\cdots \\
\cdots\end{array}$ & $\begin{array}{l}\ldots \\
\cdots \\
\cdots\end{array}$ & $\begin{array}{l}\cdots \\
\cdots \\
\cdots\end{array}$ & $\begin{array}{l}12 \cdot 4-26 \cdot 0 \\
14 \cdot 7-21 \cdot 3 \\
18 \cdot 4-24 \cdot 1 \\
15 \cdot 6-20 \cdot 1\end{array}$ & $\begin{array}{l}17 \cdot 4 \\
16 \cdot 4 \\
20 \cdot 9 \\
17 \cdot 1\end{array}$ \\
\hline
\end{tabular}

* Manufacturer's illustrated instructions: “Scoop powder from carton using only the scoop supplied. Level each scoopful with the edge of a knife, and tip into jug." Only four of these 40 subjects used a knife.

TABLE III-Weights of Four Scoopfuls of Milk Powder X Using the Appropriate Scoop. Manufacturer's Intended Weight of Milk Powder is $16 \cdot 4 \mathrm{~g}^{*}$ Spraydried Preparation.

\begin{tabular}{|c|c|c|c|c|c|c|}
\hline \multirow{2}{*}{\multicolumn{5}{|c|}{ Groups of Subjects }} & \multicolumn{2}{|c|}{ Weight of Powder (g) } \\
\hline & & & & & \multirow{2}{*}{$\begin{array}{c}\text { Range } \\
14 \cdot 0-20 \cdot 2 \\
12 \cdot 9-19 \cdot 2 \\
15 \cdot 4-18 \cdot 0 \\
15 \cdot 4-18 \cdot 9\end{array}$} & \multirow{2}{*}{$\begin{array}{c}\text { Mean } \\
17.0 \\
16.8 \\
16.7 \\
17.4\end{array}$} \\
\hline 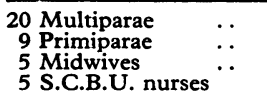 & $\begin{array}{l}\ldots \\
\cdots \\
\cdots\end{array}$ & $\begin{array}{l}\ldots \\
\cdots \\
\cdots\end{array}$ & $\begin{array}{l}\cdots \\
\cdots \\
\cdots\end{array}$ & $\begin{array}{l}\ldots \\
\cdots \\
\cdots\end{array}$ & & \\
\hline Knife used for levelling & $\ldots$ & $\ldots$ & $\ldots$ & $\ldots$ & $14 \cdot 2-19 \cdot 2$ & $16 \cdot 8$ \\
\hline
\end{tabular}

"Manufacturer's illustrated instructions: "Measure out powder with the scoop pro vided in each tin. Pack the powder down firmly and scrape level with a table knife."
valure

TABLE IV-Weights of Four Scoopfuls of Milk Powders $C$ and $Y$ Measured by Five Subjects. Intended Weights of Powder $14.0 \mathrm{~g}$ in each Preparation.*

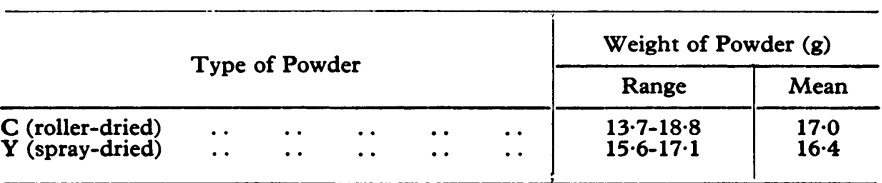

*Manufacturer's instructions:

Milk C. "Powder should be measured with the scoop provided by your Welfare Centre. A scoop contains approximately $t \mathrm{oz}$. Always level off the measure with the ack of a knife.

Milk Y. "Add correct amount of powder (LEVEL scoopfuls)."

The two most important variables seemed to be, firstly, the design of the scoop and, secondly, the type of powder-whether roller-dried or spray-dried.

\section{DESIGN OF MILK SCOOPS}

The design of five scoops from the milk preparations tested are shown in the figure, and table $\mathrm{V}$ gives the various dimensions.

Each scoop was next filled with the appropriate milk powder, first lightly, then with moderately firm packing, and finally with tight packing and no levelling. The results are recorded in table VI.

TABLE v-Dimensions of Five Scoops Illustrated

\begin{tabular}{|c|c|c|c|c|c|}
\hline $\begin{array}{c}\text { Milk } \\
\text { Powder }\end{array}$ & $\begin{array}{c}\text { Internal } \\
\text { Diameter }\end{array}$ & $\underset{\substack{\text { Depth } \\
(\mathbf{m m})}}{\text { Maximum }}$ & $\underset{\text { Depth }}{\text { Diameter }} \div$ & $\underset{(\mathrm{ml})}{\text { Volume }}$ & $\begin{array}{c}\text { Intended } \\
\text { Weight of } \\
\text { Powder (g) }\end{array}$ \\
\hline $\begin{array}{l}. . \\
\because \\
\because \\
.\end{array}$ & $\begin{array}{l}42 \\
32 \\
32 \\
25 \\
25\end{array}$ & $\begin{array}{l}10.0 \\
12.0 \\
15.0 \\
19.0 \\
14.5\end{array}$ & $\begin{array}{l}4 \cdot 2 \\
2 \cdot 7 \\
2 \cdot 1 \\
1 \cdot 3 \\
1 \cdot 7\end{array}$ & $\begin{array}{r}11.2 \\
9.6 \\
11.3 \\
7.4 \\
7.6\end{array}$ & $\begin{array}{l}3.2 \\
3.5 \\
3.5 \\
4 \cdot 1 \\
3.5\end{array}$ \\
\hline
\end{tabular}




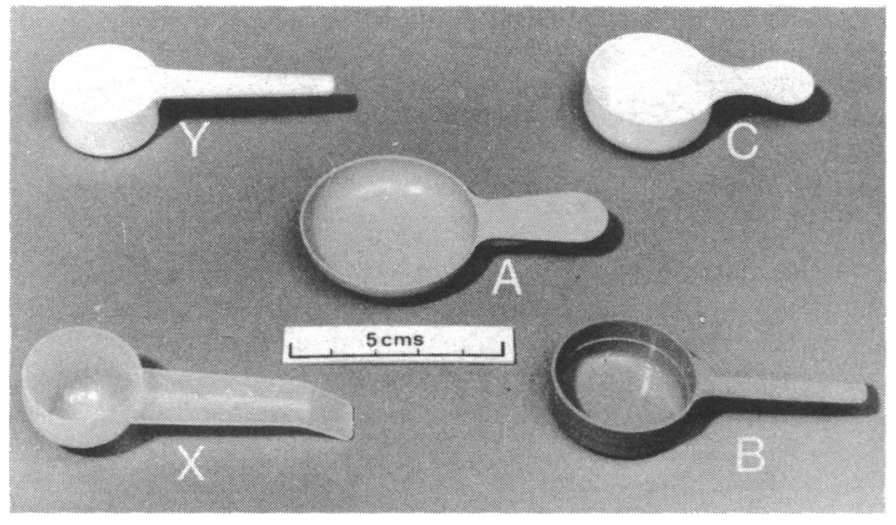

Scoops supplied with milk preparations tested.

TABLE vI-Effect of Different Degrees of Packing of the Five Milk Powders in Appropriate Scoops. Weight of Powder in Four Scoops in Grammes

\begin{tabular}{|c|c|c|c|c|c|c|}
\hline \multicolumn{2}{|c|}{ Milk } & $\begin{array}{l}\text { Lightly } \\
\text { Packed }\end{array}$ & $\begin{array}{l}\text { Moderately } \\
\text { Packed }\end{array}$ & $\begin{array}{l}\text { Tightly } \\
\text { Packed }\end{array}$ & $\begin{array}{c}\text { Intended } \\
\text { Weight }\end{array}$ & $\begin{array}{c}\text { Range of } \\
\text { Variation on } \\
\text { Intended }\end{array}$ \\
\hline $\begin{array}{l}\mathbf{A} \\
\mathbf{B} \\
\mathbf{C} \\
\mathbf{X} \\
\mathbf{Y}\end{array}$ & $\begin{array}{l}\ldots \\
\cdots \\
\cdots\end{array}$ & $\begin{array}{l}10.8 \\
13.8 \\
12.0 \\
15 \cdot 7 \\
12.7\end{array}$ & $\begin{array}{l}16 \cdot 8 \\
14 \cdot 6 \\
14 \cdot 6 \\
16 \cdot 0 \\
13 \cdot 2\end{array}$ & $\begin{array}{l}24.0 \\
20.5 \\
18.5 \\
19.9 \\
17.0\end{array}$ & $\begin{array}{l}12 \cdot 8 \\
14 \cdot 0 \\
14 \cdot 0 \\
16 \cdot 4 \\
14.0\end{array}$ & $\begin{array}{l}-15 \% \text { to }+87 \% \\
=1 \% \text { to }+46 \% \\
-14 \% \text { to }+32 \% \\
-4 \% \text { to }+21 \% \\
-9 \% \text { to }+21 \%\end{array}$ \\
\hline
\end{tabular}

The powders with the least variation were spray-dried preparations and had scoops of relatively small diameter and great depth. To assess which of these factors was responsible for the greatest accuracy in measurement milks from one packet and scoops from another were used. The results of interchanging scoops are shown in table VII.

The first line of table VII shows that the measurement of a roller-dried milk in a shallow scoop is liable to over $100 \%$ variation. The second line shows that the same milk powder can be measured much more accurately in a deep scoop. The third line shows the optimal situation using a spray-dried powder in a deep scoop, while the fourth shows loss of accuracy using this powder in a shallow scoop. Thus it seems that both spray-drying and the use of a deep scoop contribute equally in reducing variation.

\section{Discussion}

If the quantities of water required to reconstitute milk powders are measured with reasonable accuracy it would seem that four of the preparations which we tested are likely to be made up in excessive strength and only one in a strength equivalent to the makers' intention. It would have been preferable to have analysed random samples of the different milks after reconstitution by mothers in their own homes, as was done by Hytten and MacQueen (1954), but the extent of such an experiment was beyond our resources.

We have considered the dangers of excessively concentrated feeds (above) and they seem to be greater than the risks of underconcentration. Despite the publication of a leading article in the British Medical fournal (1969) and many papers, some of which we have quoted, emphasizing particular errors and hazards in the reconstitution of infants' feeds, little has been done to reeducate mothers or to alert those responsible for their guidance in hospitals and clinics. The design of milk powder scoops requires examination and the quality of the printed instructions on milk packets is variable.

We believe that a much higher standard of accuracy could be achieved by revising some of the basic factors involved in the marketing and presentation of dried milk powders. There is need for research into the optimal size and shape of the scoops provided, and there seems no reason why scoops should not be standardized, although it would probably be necessary to have different types for roller-dried and spray-dried preparations. Scoops should be enclosed in packets of National Dried Milk so that there will be no temptation for mothers to use alternative scoops of inappropriate capacity. (Two scoops from proprietary milks were seen in packets of National Dried Milk on paediatric wards during the course of our experiments.)

Clear, illustrated instructions regarding the filling and levelling of scoops should be displayed in bold type on all packets of dried milk powder. Space could be gained for the directions by omitting unnecessary distracting information, which is unlikely to be of interest to mothers. It should be stated clearly that scoops must not be used for measuring water; this is done by some manufacturers.

Mothers-to-be should be given practical instruction in the preparation of milk feeds before the birth of their babies and these instructions should be repeated before they leave hospital. Those intending to breast-feed should be encouraged strongly, but they too might have to prepare occasional complementary feeds and the information would not be wasted. It should be explained as a basic principle that where manufacturers advise the addition of sugar the powdered milk should be reconstituted at slightly less than full strength. The old-fashioned recommendation of putting in one less scoop of powder than the number of ounces of water still makes good sense and provides the growing infant with an increasing strength of feed.

Most of the errors described and discussed would be eliminated if dried milk powders could be marketed in small, accurately weighed packets, to which it would be necessary only to add a stated volume of water.

We are grateful to Professor F. E. Hytten, Dr. F. J. W. Miller, and Dr. A. R. R. Cain for helpful suggestions in the preparation of this paper, to Miss M. McKeown for secretarial help, and to Mr. R. S. Noble for technical help.

Requests for reprints should be sent to Dr. T. C. Noble, Newcastle General Hospital, Newcastle upon Tyne NE4 6BE.

\section{References}

British Medical fournal, 1969, 4, 515.

Colle, E., Ayoub, E., and Raile, R. (1958). Pediatrics, 22, 5.

Eid, E. E. (1970). British Medical Fournal, 2, 74.

Finberg, L., and Harrison, H. E. (1955). Pediatrics, 16, 1.

Hytten, F. E., and MacQueen, I. A. G. (1954). Lancet, 2, 836.

Illingworth, R. S. (1972). Midwives Chronicle and Nursing Notes, 86, 120.

Polácek, E., Vocel, J., Neugebauerová, L., Selková, M., and Véchetová, E. (1965). Archives of Disease in Childhood, 40, 291 .

Shukla, A., Forsyth, H. A., Anderson, C. M., and Marwah, S. M. (1972). British Medical fournal, 4, 507

Taitz, L. S. (1971). British Medical fournal, 1, 315

Taitz, L. S., and Byers, H. D. (1972). Archives of Disease in Childhood, 47, 257.

Winberg, J. (1959). Acta Paediatrica, 48, 318.

Ziegler, E. E., and Fomon, S. J. (1971). Fournal of Pediatrics, 78, 561.

TABLE VII-Roller-dried and Spray-dried Milks Measured in Shallow and Deep Scoops

\begin{tabular}{|c|c|c|c|c|c|c|c|c|c|c|c|}
\hline \multirow{2}{*}{\multicolumn{6}{|c|}{ Milk Powder }} & \multirow{2}{*}{ Type of Scoop } & \multirow{2}{*}{$\begin{array}{l}\text { Diameter/Depth } \\
\text { Ratio of Scoop }\end{array}$} & \multicolumn{3}{|c|}{ Weight of Powder in Four Scoops (g) } & \multirow{2}{*}{$\begin{array}{c}\% \text { Variation } \\
\text { Lowest-Highest }\end{array}$} \\
\hline & & & & & & & & Lightly Packed & Moderately Packed & Tightly Packed & \\
\hline $\begin{array}{l}\text { A (roller) } \\
\mathbf{A} \text { (roller) } \\
\mathbf{X} \text { (spray) } \\
\mathbf{X} \text { (spray) }\end{array}$ & $\begin{array}{l}\ldots \\
\because \\
\cdots\end{array}$ & $\begin{array}{l}\ldots \\
\cdots \\
\cdots\end{array}$ & $\begin{array}{l}\ldots \\
\cdots \\
\cdots\end{array}$ & $\begin{array}{l}. \\
\therefore \\
.\end{array}$ & $\begin{array}{l}. \\
\cdots \\
.\end{array}$ & $\begin{array}{l}\mathbf{A} \\
\mathbf{x} \\
\mathbf{x} \\
\mathbf{A}\end{array}$ & $\begin{array}{l}4 \cdot 2 \\
1 \cdot 3 \\
1 \cdot 3 \\
4 \cdot 2\end{array}$ & \begin{tabular}{r|}
$10 \cdot 8$ \\
$7 \cdot 8$ \\
$15 \cdot 7$ \\
$18 \cdot 0$
\end{tabular} & $\begin{array}{r}16.8 \\
8.9 \\
16.0 \\
23.5\end{array}$ & $\begin{array}{l}24 \cdot 0 \\
12.8 \\
19 \cdot 9 \\
29 \cdot 0\end{array}$ & $\begin{array}{r}122 \\
64 \\
27 \\
61\end{array}$ \\
\hline
\end{tabular}

